\title{
THE MEANING OF PATIENCE IN ISLAMIC PSYCHOLOGICAL PERSPECTIVE: A LIFE EFFORT FOR PHYSICAL DISABILITIES
}

\author{
${ }^{1}$ Lusia Hani, ${ }^{2}$ Iredho Fani Reza, ${ }^{3}$ Abu Mansur \\ 123 Universitas Islam Negeri Raden Fatah Palembang, Indonesia. \\ ${ }^{2}$ Corresponding Author: iredhofanireza_uin@radenfatah.ac.id
}

\begin{abstract}
This study aims to find out how people with physical disabilities understand the meaning of patience in an effort to live life. Using qualitative research with a phenomenological research design. Sampling using purposive sampling technique, namely 6 subjects consisting of men and women with physical disabilities. Methods of data collection using interviews, observation and documentation. While the data analysis method uses an interactive model which consists of three stages, namely data condensation, data display and conclusions: drawing. The results of this study conclude that the meaning of patience for people with physical disabilities is trying to stay calm, not complaining and not doing bad things and not doing things that are forbidden by Allah SWT by surviving and struggling, limiting themselves, Refrain from people's ridicule and always be optimistic about life. The factors that affect patience in people with physical disabilities are religiosity and social support.
\end{abstract}

Keywords: Meaning, Patience, People with Physical Disabilities

\section{INTRODUCTION}

Humans are essentially created by God in the best possible form with different strengths and weaknesses. Every human being certainly wants to be able to live a normal life according to the expected plan, but in the span of his life he will always be faced with a reality that often makes humans confused.

Ubaedy(2007) revealed that what often confuses people is reality because in reality there are problems that arise suddenly.-Sometimes there are things that are in accordance with the wishes but more often than not they are contradictory.

Fad'aq (2002) states that Allah SWT made the life of the world based on a changing and changing nature. Sometimes some people are destined to suffer various kinds of trials. Likewise, if a person has an accident and eventually causes a person to experience a lifelong disability, be it hand, leg, back or other limb defects.

Meanwhile, according to Somantri, physical disability is a condition that is damaged or disturbed as a result of impaired shape or obstacles to bones, muscles, and joints in their normal function.(Somantri, 2006).

Based on UN data, 10 percent of the total world population or about 650 million people are people with disabilities. In Indonesia alone, based on data from the Ministry of Social Affairs, the number of People with Social Welfare Problems (PMKS), which includes persons with disabilities, is 1.7 million people.(Princess S, 2015).

With different types and causes. Based on the definition published by the Ministry of Social Affairs in 2005, the types and causes of disability are divided into 3 (three) namely: Disability due to accidents, including victims of war, riots, work/industrial accidents, traffic accidents and other accidents; Disabilities from birth or in the womb, including this group are those with disabilities due to hereditary diseases; Disability caused by disease, including polio, venereal disease, tuberculosis, leprosy, diabetes, and others(Nuryetty, 2012).

In addition, physical disabilities can also cause adjustment problems. Because self- 
adjustment is strongly influenced by the reactions of other people in their environment. With the support and sense of security in the family environment, it will help someone adjust to the social environment(Semiun, 2006).

Humans should be patient for something that has been destined for him, surrender and be willing to Allah's qodho, that is the right way to go through the biggest test. Because patience does not escape tests and trials. Patience is not considered perfect if an individual has not been tested and calamity has been sent down to him. A person's patience can be influenced by: knowing the nature of worldly life, believing in a good reward in the sight of Allah, knowing the nature of oneself, believing that there is a way out, asking Allah for help, and believing in Allah's qadha and qadar.(Ubaid, 2012).

Patience according to Subandi(2015) can be categorized into five, namely: selfcontrol, steadfastness, persistence, accepting the harsh reality with sincerity and gratitude and a calm attitude, not in a hurry.

Every situation experienced and all things that humans encounter in this world cannot be separated from two things, namely something that is in accordance with their wishes and something that is against their will. (Ubaid, 2012).

As happened to people with disabilities as stated by Nahar, Director of Social Rehabilitation of People with Disabilities, who stated that currently there are still people who have not received attention from their families because they are ashamed to have family members with disabilities. And also the lack of attention from the community due to the lack of public knowledge about the availability of social rehabilitation services to help people with disabilities whose special function is to provide social protection.(Princess S, 2015).

Panti Sosial Bina Daksa (PSBD) "Budi Perkasa" Palembang is a place for Social Services and Rehabilitation of the Ministry of Social Affairs of the Republic of Indonesia with the main task of carrying out physical, mental, social development, skills training and resocialization as well as further coaching for people with physical disabilities so that they are able to play an active role in social life. . At the Bina Daksa Social Institution "Budi Perkasa" Palembang itself accommodates approx \pm 120 people ranging in age from 15 years to 35 years, with various kinds of disabilities, such as cerebral palsy, polio, disability due to amputation, and others.

Based on the results of observations and interviews conducted by researchers in the field, not all people with physical disabilities after accidents tend to suffer from their physical disabilities. As stated by several people with physical disabilities after the accident at the Bina Daksa Social Institution (Budi Perkasa) Palembang.

The subject with the initials $N$ : “... at first he just locked himself at home, often mocked by his friends. But now when I leave the house I have started to be brave and also when friends who insulted me try to hold back their emotions so they don't get angry by just being silent and I continue to try to be patient with the current conditions because one day there must be a lesson and also since coming here I have become more grateful. Many of these orphanages have more disabilities than me."

The subject with the initials RK: "... accept sincerely and patiently my condition, the name of life may have been written from God and it must be lived". The subject with the initials $\mathrm{K}$ : "I am grateful that there are still many whose conditions are worse than me, and are still given the opportunity to live because life is still long and must learn as well as possible in order to compete with other people out there".

The subject with the initials PS: "until now still can't accept it."

Patience is certainly very beneficial for aspects of human life. As according to alGhazali stated that patience has great benefits for human life. With patience a person can get a high degree and many goodness such as good character, controlling lust, getting guidance, help, mercy, forgiveness, piety, joy, and peace of mind and closeness to Allah SWT.(Al Ghazali, 2005). 
Based on the explanation above and the phenomena that the researchers encountered in the field, the researchers were interested in studying this matter in greater depth and raised it in a study whose research question focused on revealing the meaning of patience in Persons with Physical Disabilities.

\section{RESEARCH METHODS Types of research}

This study uses a qualitative research design with a phenomenological research design which is aresearch that describes the meaning of several individuals regarding their life experiences, the meaning of certain concepts or phenomena(Martono, 2016). The main purpose of phenomenological research is to produce a clear, precise and systematic picture and to explain the meaning of the thing studied through descriptive data.

\section{Research subject}

The technique used to determine the subject in this study is purposive sampling. Purposive sampling is a sampling technique of data sources with certain considerations.(Sugiyono, 2016). The criteria for the subjects in this study are as follows:

1. Individuals undergoing coaching at the Budi Perkasa Panti Sosial Bina Daksa (PSBD) Palembang from 2015, 2016, and 2017.

2. Individuals with physical disabilities due to accidents.

3. Individuals who are male and female aged 18 - 40 years(B Hurlock, 2004).

4. Individuals who are Muslim.

5. The individual concerned is willing to be the subject of the research.

\section{Data Collection Method}

The purpose of this data collection technique is to obtain data. The data collection technique used in this study is a combination of interview, observation, and documentation techniques. The main technique is interviews which are used semi-structured interviews(Sugiyono, 2016).

\section{Data analysis method}

Qualitative data analysis is an effort made by working on the data, organizing the data, sorting it into manageable units, synthesizing it, looking for and finding patterns, discovering what is important and what is learned and deciding what can be told to others.(Sugiyono, 2016). The data analysis technique used is an interactive model data analysis technique which consists of three stages, namely data condensation, data display and conclusions: drawing.(Miles et al., 2014).

\section{Validity of Research Data}

As for testing the validity of the data the researchers did, namely the credibility test of the data.As for the plan to conduct this credibility test, namely the extension of observations, triangulation, conducting member checks(Moleong, 2013).

\section{RESEARCH RESULT}

\section{Research Subject Demographics}

In this study involved 6 research subjects which the researchers coded: N, AN, K, RK, PS, and AF. In addition, there are 9 supporting informants $\mathrm{K}, \mathrm{NH}, \mathrm{MT}, \mathrm{WM}, \mathrm{H}$, SMN, S, SH, and SA. In detail for the subjects in this study as shown in the table below:

Table 1. Subject's sex and age

\begin{tabular}{ccc}
\hline $\begin{array}{c}\text { Subject } \\
\text { Code }\end{array}$ & Sex & age \\
\hline $\mathrm{N}$ & Female & 37 \\
\hline $\mathrm{AN}$ & Female & 20 \\
\hline $\mathrm{K}$ & Male & 28 \\
\hline $\mathrm{RK}$ & Male & 27 \\
\hline $\mathrm{PS}$ & Male & 20 \\
\hline $\mathrm{AF}$ & Male & 19 \\
\hline
\end{tabular}

\section{Research Subject Background}

The themes that appear in the background of life episode are the background of the informant, having an accident, and family support.

The background theme is the theme for each informant. In this case experienced by informants with the initials $\mathrm{N}, \mathrm{AN}, \mathrm{K}, \mathrm{RK}$, $P S$ and $A F$. All informants have different 
life backgrounds ranging from regional origins, activities, ages, types of education.

$\mathrm{N}$ revealed that he was from the Ogan Komering Ulu area of Timur, 37 years old, the youngest of four children, N's educational background was only a primary school graduate. $\mathrm{N}$ was previously married at the age of 18 and has one daughter, but in $2002 \mathrm{~N}$ decided to separate from her husband due to domestic violence. Then $\mathrm{N}$ finally decided to migrate to Pekanbaru and work in one of the restaurants there. And then AN revealed that he was also from the OKU area to be precise Baturaja, 20 years old, the 2nd child of eight siblings, AN's educational background was only elementary school graduates, AN decided to get married at the age of 18 but the marriage only lasted approximately one month AN is divorced by her husband. Previously, AN worked as a waitress in one of the food stalls in her area, then decided to stop and AN's activities after that only looked after her younger siblings at home. Then $\mathrm{K}$ comes from the Kampar Riau area, 27 years old, educational background is a high school graduate, previously $\mathrm{K}$ worked as an e-ID card operator for six months, after that selling clothes then in $2014 \mathrm{~K}$ worked as an electrical installation installer for about 5 months. month. While RK is from Empat Lawang district, 26 years old, the youngest of ten children with an educational background of junior high school graduates, RK's previous activities were only attending school. Then $\mathrm{K}$ comes from the Kampar Riau area, 27 years old, educational background is a high school graduate, previously $\mathrm{K}$ worked as an e-ID card operator for six months, after that selling clothes then in $2014 \mathrm{~K}$ worked as an electrical installation installer for about 5 months. month. While RK is from Empat Lawang district, 26 years old, the youngest of ten children with an educational background of junior high school graduates, RK's previous activities were only attending school. Then $\mathrm{K}$ comes from the Kampar Riau area, 27 years old, educational background is a high school graduate, previously $\mathrm{K}$ worked as an e-ID card operator for six months, after that selling clothes then in $2014 \mathrm{~K}$ worked as an electrical installation installer for about 5 months. month. While RK is from Empat Lawang district, 26 years old, the youngest of ten children with an educational background of junior high school graduates, RK's previous activities were only attending school.

Meanwhile, PS is from Pali district, 20 years old, the youngest of 7 siblings, PS educational background is that he has not graduated from junior high school, PS activity at that time was studying in junior high school. Similar to PS, AF also revealed that he was from Banyuasin district, precisely in the Pangkalan Balai area, 19 years old, the fifth child of 7 children, AF's previous activity was studying at junior high school.

Because they have different backgrounds, an adaptation process is needed with other people with other physical disabilities.

\section{Got an accident}

This theme was experienced by research informants with the initials $\mathrm{N}, \mathrm{AN}, \mathrm{K}, \mathrm{RK}$, PS and AF. Some of the informants had different accidents. The following are the expressions of research informants related to the theme of the informant having an accident.

$\mathrm{N}$ revealed that he had an accident on his way home from work on Wednesday, at 15.30 WIB in 2013. At that time $\mathrm{N}$ helped a small child who was crossing the highway but finally $\mathrm{N}$ was hit by a car, AN had to be treated at the hospital for two months and had his right leg amputated, making him a physically disabled person.

Unlike $\mathrm{N}, \mathrm{AN}$ revealed that when he was 2 years old, $\mathrm{N}$ hit an incandescent lamp in his house which resulted in burns on his body, specifically on his hands and face. After undergoing treatment in the hospital for more than a year, AN was brought home by her parents due to lack of funds, and AN's father also removed the assistive device that was attached to AN's left hand because he could not bear to see $A N$ in pain. This resulted in N's hand not growing like a normal person. So now $A N$ is a person with a physical disability. 
Meanwhile, $\mathrm{K}$ was electrocuted while working on an electrical installation in 2014. $\mathrm{K}$ then underwent treatment in the hospital for three months. After that $\mathrm{K}$ underwent treatment at home for six months. The accident made K's left hand amputated. So that $\mathrm{K}$ is now a physically disabled person.

Then RK had an accident after graduating from junior high school, at that time RK and his friends were visiting one of the tourist attractions in the area, when on the way home the motorbike that RK was driving had a tire burst and then lost balance so it was hit by a car. After that incident RK only underwent treatment at home without ever being taken to the hospital. Because of that, finally RK's legs don't grow like normal people.

Meanwhile, PS had an accident when he was still in high school. He often did wild races and at one point on a Friday at 22.30 WIB in 2013 the motorbike he was driving had a collision with another motorbike rider. So PS had to undergo treatment at the hospital. Because of this incident, PS's right hand can't function like a normal person's hand (can't be moved.

Similar to PS, AF also revealed that when he was in junior high school he also often did wild races with his friends and at one point on a Sunday night at around 02.00 WIB when AF was about to go home after gathering with his friends, $\mathrm{AF}$ forced to ride his motorbike through heavy rain, but the motorbike he was riding skidded which resulted in AF having a single accident and finally being taken to the hospital and undergoing treatment for about 2 weeks and requiring AF to undergo surgery to reattach his hands twice. However, the operation was not successful and resulted in AF losing his right hand.

And regarding the informant's selfresponse and his friend's response after the informant had an accident that made him physically disabled. Each informant is different, namely $\mathrm{N}$ after he had an accident and became a disability $\mathrm{N}$ felt shy, impatient, irritable, inferior, tried to hurt himself and even tried to end his life as well as the response of his friends who also started avoiding $\mathrm{N}$. AN too it's the same with $\mathrm{N}$ even though he had an accident when he was young, $\mathrm{N}$ still feels inferior, embarrassed, shuts himself up at home, can't accept his physical condition, plans to hurt himself and $\mathrm{N}$ often gets ridicule from his friends. Furthermore, $\mathrm{K}$, after he became a person with a disability, $\mathrm{K}$ locked himself at home, felt bored, still experiencing trauma and $\mathrm{K}$ was also shunned by his friends. RK also feels sad, annoyed with himself, feels left out, and has been humiliated by his friends. Furthermore, PS also felt inferior, traumatized by holding a motorcycle, unable to accept his physical condition, frustrated that he fled to drugs but his friends did not stay away from him. Then AF, AF initially also regretted, embarrassed, frustrated, and some of his friends started to drift away.

\section{Family support}

When a person experiences difficult times in his life, support from family and other people is needed to be able to restore one's enthusiasm so that they can live a better life. In this case, the support from the family received by informants $\mathrm{N}$ and AN is the same. The family provides support so that they can accept their physical condition and be more patient, the family of $\mathrm{K}$ and $\mathrm{RK}$ provide support so that they can live independently and the support that PS receives is in the form of freedom and facilitating PS's wishes.

In addition, every informant received offers to enter the orphanage from family, friends, and the local office. Each informant also has different reasons for entering the orphanage, for example $\mathrm{N}$ wants to seek knowledge, AN so that he can work, $\mathrm{K}$, wants to add skills, insights, friends and so as not to be underestimated by the community, RK was initially bored of living in his village and wanted to find a future better and PS wants to try living in a new environment in order to change his life while AF wants to go to school.

\section{Life with Disabilities}

This theme is a theme that is experienced by a person when experiencing a physical 
disability. In this case, the six research informants experienced.

After becoming physically disabled, the six informants decided to go to an orphanage. When they first entered the Bina Daksa Budi Perkasa Social Institution in Palembang, the informants had different initial impressions. Namely $\mathrm{N}$ was initially uncomfortable. AN was initially shocked, but grateful that her physical disability was not as severe as that of other orphanages. $\mathrm{K}$ was initially bored but also grateful that his physical disability was not as bad as other nursing home staff, and $\mathrm{K}$ became motivated to respect others. RK was initially surprised but also grateful that his physical disability was not as bad as other nursing home staff. PS admitted that he was sad and remembered the bad things he had done and that made PS grateful that his physical disability was not as bad as other nursing home staff. AF said he was grateful that his physical disability was not as bad as other nursing home staff and he could still do many activities.

\section{Patience in Living Life}

As a person with a physical disability, of course, he will experience difficulties in carrying out activities and with physical disabilities experienced after adulthood, of course, the informant will be more sensitive and easily offended. In undergoing coaching at the orphanage, of course, research informants must be patient, especially in their activities and in interacting with fellow nursing staff. As stated by research informants, $N$ revealed that at first it was difficult to follow women's craft skills, but by continuing to learn, finally $\mathrm{N}$ was able to make crafts. Regarding fellow nursing home staff who sometimes irritated $\mathrm{N}, \mathrm{N}$ initially had a fight but now it doesn't happen again, $\mathrm{N}$ admitted that he entered the orphanage to study and not to make enemies. The way $\mathrm{N}$ solves the problems he is experiencing is asking Allah for a way out through prayer because awareness is also obtained through prayer, and discussing problems with the person concerned. And for $\mathrm{N}$ to be able to get through the calamity that befell him, that is by being grateful for his life now.

Furthermore, AN, in following women's craft skills, especially sewing, to be able to sew AN learns for one month and that requires patience. When fellow nursing home staff irritated him, AN preferred to remain silent and ignore him. And when experiencing a problem, the way that AN does to solve the problem is to ask Allah for the best way out through prayer. In addition, by sharing with friends and discussing the problem with the person concerned.

Next, $K$, regarding his patience with his fellow nursing home staff, $K$ prefers selfintrospection, negotiates problems that occur and of course has to be patient and share with friends he trusts. In addition, $\mathrm{K}$ chose to calm himself down with ablution, pray and pray to Allah so that he would be given a way out of the problems he was facing. And for $\mathrm{K}$, he was able to survive life despite having a physical disability, thanks to the support from his family.

Furthermore, RK, for RK, his patience in doing activities while at the orphanage was that at the beginning he did not use a cane so he had difficulty walking and he had to be patient in participating in various activities with a distance from his dormitory which was quite far from the skill area he was participating in. RK also admitted that many of his fellow orphanages provoked his anger but RK understood it, and he tried to adjust and be patient. RK also revealed that by praying and reading the Koran, playing musical instruments is a way for him to be able to deal with every problem he experiences. And being grateful, sincere and open-hearted is RK's way of being able to live life with the physical disabilities he experiences.

Then AF, in following electrical skills, initially $A F$ had difficulty but he was motivated by the patience and enthusiasm of his friend who has a more severe physical disability than $A F$, so $A F$ continued to try and be enthusiastic in following these skills. In dealing with nursing home staff who sometimes provoke emotions, AF prefers to remain silent but still tries to be friendly to others. 
When experiencing a problem, AF's way to solve it is to pray to calm the mind, reflect a lot. And with the support of his parents, AF was able to live life even with the physical disabilities he experienced.

Meanwhile, PS admitted that he had difficulty keeping up with his electrical skills, PS even slammed or hit the electronic equipment he was using, besides that PS had also had a fight with his dorm mates at the orphanage. PS rarely shares with others about the problems he experiences, PS admits that he doesn't trust other people.

\section{Process For Patience}

On the theme of the process of being patient, informant $\mathrm{N}$ revealed that now he has accepted the physical disability he experienced by being grateful for his life which is still lucky than others and admits that he is more patient than before, for $\mathrm{N}$ with being patient there will be progress in his life and his bitter past. Take lessons so it doesn't happen again. And the most important thing for $\mathrm{N}$ now is to continue to multiply worship to Allah SWT.

AN also admitted that he could not accept the physical disability he experienced, but AN admitted that he had experienced many changes during his stay at the orphanage, namely being more patient than before in a lesson. This is because of advice from the orphanage. For $\mathrm{N}$, his past is a lesson to become a better person in the future and AN also admits that by being patient he feels calm in living life.

Dan $\mathrm{K}$ revealed that he had accepted his physical disability. This is because the worship performed by $\mathrm{K}$ is praying, and praying to Allah, as well as the support from his output. $\mathrm{K}$ also admitted that now he is more patient than before. Because by being patient, life becomes calmer and can live life better than before. The patience that $\mathrm{K}$ feels is obtained through prayer.

Next, it was RK who revealed that he had accepted the physical handicap he had. According to him, he should be able to let go of what happened and use the experience as a lesson to become a more patient person. RK expresses that by being patient the mind becomes calmer and RK also hopes to invite others to do good.

Next PS admitted that he could not accept the physical disability he experienced and still regrets his past, especially the accident that made him physically disabled. For PS, patience is a way to control emotions, which according to him is sometimes still difficult to control.

PS stated that while in the orphanage he slowly tried to control himself even though there was time to be patient and only necessary, SR said that PS needed more attention and time to change.

Then AF admitted that he had accepted the physical disability he experienced, AF considered his disability the best so that he could improve himself. AF also revealed that before three months of the accident he had begun to learn to be patient and after being at the orphanage there was a change in his patience, which was more and more. This is because of the support from his parents, and the worship he does, as well as making his life experience a lesson to become a better person than before.

\section{Factors Affecting Patience}

Furthermore, the six research informants revealed the factors that made them more patient than before, namely differently according to $\mathrm{N}$, namely by praying because with prayer $\mathrm{N}$ became more patient. According to AN, they are good friends and advice from the orphanage and life experiences that make him a more patient person than before.

According to $\mathrm{K}$, that is because of the journey of life and support from parents. According to RK, that is close to God and learn from life experiences. According to PS, that is because of the motivation of the orphanage. And according to AF, that is because of worship and always remember the parents.

\section{MeaningPatience}

On the theme of the meaning of patience, each informant expresses the meaning of patience for himself, namely $\mathrm{N}$ reveals that patience for him is full of calm thoughts. AN revealed that the meaning of patience 
for him is not complaining, not doing bad things and things that are forbidden by Allah SWT.

For $\mathrm{K}$, patience is to endure gracefully on Allah's test. RK reveals that patience is a way to fight in the way of Allah so that Allah's wishes can be granted so that it can bring success and happiness in life. PS said patience is limiting oneself so as not to be provoked by emotions. And patient $\mathrm{AF}$ is to withstand ridicule and ridicule and always be optimistic.

\section{DISCUSSION}

This study shows that the subject, namely people with physical disabilities after accidents, has different experiences in the transformation of patience in themselves. These stages are indicated by the themes that appear in each episode.

As described in the episode life background, some of the subjects said that the subjects came from different regional and educational backgrounds and professions. Prior to having an accident and finally having to become a person with a disability, subject $\mathrm{N}$ who came from East OKU was an elementary school graduate, and had been married and worked. Subject AN who came from Baturaja had previously been married, worked and was an elementary school graduate, Subject $\mathrm{K}$ who came from Kampar Riau was a high school graduate and had worked. RK's subjects from the Empat Lawang area are junior high school graduates. And the subject of PS is from Pali and is an elementary school graduate, and AF is from Banyuasin who is a junior high school graduate.

Because of the different backgrounds so that when in the orphanage it is necessary to adjust to the new environment. Because adjustment is the most important factor in human life(Sobur, 2011).

In the perspective of Islamic psychology, because humans cannot live alone without the help of others so that each subject must also know each other, as $\mathrm{O}$ humans, Indeed We created you from a male and a female and made you into nations and tribes. -tribes so that you may know each other..." [QS. al-Hujurat (49): 13].

The stronger the recognition of one party with another party, the more open the opportunity to provide benefits. Because the verse above emphasizes getting to know each other. This introduction is needed to draw lessons from each other and the experiences of others, in order to increase piety to Allah SWT, whose impact is reflected in the peace and prosperity of this worldly life and the happiness of the hereafter.(Shihab, 2018).

Subjects have different experiences regarding the chronology of the accidents they experience. $\mathrm{N}$ was hit by a car while rescuing a child who was about to cross the highway. AN suffered burns due to accidentally touching an incandescent lamp. $\mathrm{K}$ was electrocuted while working on an electrical installation. RK is hit by a car while riding a motorbike. PS had a collision with a fellow motorcycle driver. And AF had a single accident while riding a motorcycle.

The sudden arrival of a disaster will shake the soul and worry the heart, so that someone who is struck by a disaster will feel deep sorrow and even lose their minds. In conditions like this, the devil will easily control humans so that he will do actions that remove the reward and bring God's wrath(Ubaid, 2012).

The physical condition of the subject who used to be normal and can do many activities without any limitations but after an accident will certainly have a huge impact on the life of the subject. On the theme of having an accident. Each subject responded in various ways such as feeling embarrassed, impatient, irritable, feeling inferior, trying to hurt himself and even trying to end his life. AN is insecure, embarrassed, confined at home, unable to accept his physical condition, plans to injure himself. Furthermore, $\mathrm{K}$ locked himself at home, feeling bored, still experiencing trauma and $\mathrm{K}$ was also shunned by his friends. RK feels sad, annoyed with himself, feels left out. Furthermore, PS also felt inferior, traumatized by holding a motorcycle, unable to accept his physical condition, frustrated that he fled to drugs. Then AF, 
In line with Senra also revealed that people with physical disabilities who experience amputations due to accidents certainly have a negative psychological impact on the situations they experience, such as depression, trauma, anger, suicide, and sadness. (Puspasari \& Alfian, 2012)

In fact, people who have recently experienced a disability are more likely to show emotional disturbances. This is in accordance with Somantri's opinion which states that a certain age limit will affect a person's rate of development. Disability experienced at an older age shows a smaller effect on the rate of development but causes a greater psychological impact. And when someone has just experienced a disability like that experienced by the subject, he will show a rejection reaction, but the longer he experiences it, he will be able to accept the disability he suffers so that he is able to adapt better to his environment.(Somantri, 2006).

In the perspective of Islamic psychology, an accident can be a calamity which is one of the tests from Allah to His servants so that people who are able to be patient can know about the calamities they experience. As stated, "And indeed We will give you a trial, with a little fear, hunger, lack of wealth, soul and fruit. and give glad tidings to those who are patient" [QS. albaqarah (2):155].

With the condition of disability experienced by the subject, of course, it will be difficult for them to do activities as they did before the accident, so their very support is needed to be able to get through difficult times in their lives, in this case the most important thing is support from family From the expressions of all subjects, families, especially parents, always provide support, especially emotional support.

Emotional support is a form of social support received by the subject in the form of attention and affection given by someone to others. The form of attention and affection given to individuals with disabilities has a positive impact on the social and psychological development of the subject.
According to Somantri, a positive form of treatment for individuals with disabilities shows a tendency to neutralize the social development of individuals due to the condition of the disability (Somantri, 2006).

With the support from family and friends, the spirit in the subject began to grow, this could be seen from the subject's decision to enter the Bina Daksa Budi Perkasa social home in Palembang. Each subject has a different reason why he decided to enter the orphanage. Among them, $\mathrm{N}$ reasoned that he wanted to seek knowledge. $\mathrm{K}$ wants to add skills to be able to work. RK feels bored, embarrassed to live in the village and wants to find a better future. PS want to try a new environment. And AF wants to continue his schooling.

From the reason the subject entered the orphanage, it can be seen that there was a spirit of wanting to change in the subject, namely wanting to live a better life than what he is living now. In the perspective of Islamic psychology, indeed changes occur there should be an effort made by the person, "Indeed Allah does not change the condition of a people so that they change the situation that is in themselves..." [QS. al. Ra'd (13): 11].

Then on the episode of life in the orphanage. In the episode of life in the orphanage, the theme of disability life Subjects have different initial impressions, such as surprised, strange, bored or bored, sad and also grateful. Although initially the subject is not used to the new environment, it is something that is usually experienced by someone when they are in a new environment.

So it requires a process to be able to adapt. The process of adjustment is formed according to the relationship of the individual, not only changing his behavior in dealing with his needs from inside and outside conditions, in the environment in which he lives, but he is also required to adjust to the presence of other people and their various activities.(Sobur, 2011).

The expressions of the six research subjects in addition to trying to adjust to the new environment but basically indicate that the subject begins to realize that he is still lucky compared to his friends at the 
orphanage who have more severe physical disabilities than him. This raises the subject's gratitude to Allah SWT.

People who are always grateful to Allah are people who always try to measure themselves with people whose situation is more or less even more sad than the situation they are in. (Amen, 2003).

Next is the theme of being patient in living life. Next is the theme of being patient at the orphanage. In undergoing coaching at the orphanage, of course, the research subject must be patient, especially in activities and in interacting with fellow nursing home staff. As stated by the research subject, $\mathrm{N}$ said that at first it was difficult to follow women's craft skills, but by continuing to learn, finally $\mathrm{N}$ was able to make crafts.

Regarding fellow nursing home staff who sometimes irritated N, N initially had a fight but now it doesn't happen again, $\mathrm{N}$ admitted that he entered the orphanage to study and not to make enemies. Furthermore, AN, in following women's craft skills, especially sewing, to be able to sew AN learns for one month and that requires patience.

When fellow nursing home staff irritated him, AN preferred to remain silent and ignore him. Next, $\mathrm{K}$, regarding his patience with fellow nursing home staff, $\mathrm{K}$ prefers self-introspection, negotiates problems that occur and of course has to be patient. Furthermore, RK, for RK, his patience in doing activities while at the orphanage was that at the beginning he did not use a cane so he had difficulty walking and he had to be patient in participating in various activities with a distance from his dormitory which was quite far from the skill area he was participating in.

RK also admitted that many of his fellow orphanages provoked his anger but RK understood it, and he tried to adjust and be patient. RK also revealed that praying and reciting the Koran is a provision to feel at home in the orphanage.

Then AF, in following electrical skills, initially $A F$ had difficulty but he was motivated by the patience and enthusiasm of his friend whose disability was more severe than AF, so AF continued to try and be enthusiastic in following these skills.

In dealing with nursing home staff who sometimes provoke emotions, AF prefers to remain silent but still tries to be friendly to others. Meanwhile, PS admitted that he had difficulty keeping up with his electrical skills, PS even slammed or hit the electronic equipment he was using, besides that PS had also had a fight with his dorm mates at the orphanage.

In the perspective of Islamic psychology, when experiencing problems or bad treatment from other people, sometimes humans can only hate and take revenge for themselves. Although replying is allowed, patience is more important. As the word of Allah SWT, "And if you give a recompense, then recompense with a retribution equal to the torment that was inflicted on you, but if you are patient, verily that is better for those who are patient" [QS. an-Nahl (16):126].

In the perspective of Islamic psychology, the intention is to survive so as not to overreact that will make us lose. Patience here is waiting for the emergence of positive emotions from us so that the steps we take are not detrimental. As in the word of Allah SWT, "But those who are patient and forgive, Verily (actions) like that are among the things that take precedence" [QS. ash-Shura (42): 43 ].

In the perspective of Islamic psychology, it means that if you receive bad treatment from others, then being patient and forgiving is better than repaying with evil. Every Muslim needs patience, especially in the face of calamity. In dealing with this, he must always rely on Allah's promise of a good reward for his patience. With difficulties, the reward will continue to accompany. Therefore he is required to be patient as Allah says "... and be patient with what befalls you. Verily, that is one of the things that are obligatory (by Allah)" [QS. Luqman (31): 17].

Before being in the orphanage, the subject already had the provision of religious education from parents and teachers. However, because the social environment is not good, the research 
subjects are lazy to carry out worship such as praying, reading the Koran, and so on.

Especially after having an accident and being a person with a physical disability. When in the orphanage, the subject began to be enthusiastic about carrying out worship, especially the support from the orphanage, namely the existence of religious education that was taught such as prayer, Koran, lectures, and so on.

But for the subject of PS, he admits that he feels calm when praying but he is still lazy to worship, because for PS when he asks for calm from Allah so he can control his anger, he has not felt calm. And for other subjects such as N, AN, K, RK and $A F$, by carrying out worship, especially prayer, reading the Koran, life is more focused, the solution to every problem and with prayer the mind will become calm.

The expression of the five research subjects above is in line with the expression of Uthman Najati who stated that the establishment of a Muslim before Allah SWT will provide him with spiritual energy that causes happiness, comfort, tranquility and mental health. (Rajab, 2011).

This is supported by the results of a study conducted by Kurniawan which states that prayer can bring peace of mind and inner peace and can prevent a person from being stingy and complaining. As the word of God in QS. al-Ma'arij (70): 19-22, "Indeed, man was created to be grouchy and miserly. When trouble befalls him he complains, and when he gets good he is very stingy, except for those who pray."

Nurcholish Madjid also stated that a successful prayer will have the effect of forming a mental attitude that is free from worries that are not in place to face life. The effect of prayer on humans will produce reassurance and peace of mind that underlies optimism in living a difficult life(Reza \& Magfiroh, 2016).

The explanation above is supported by the word of Allah QS. al-Ra'd (13): 28, "(namely) those who believe and their hearts find peace in the remembrance of Allah. Remember, only in the remembrance of Allah does the heart find peace."
The last episode is patient. In this episode reveals the transformation or change in the patient's research subjects. The following is an explanation of each theme.

On the theme of the process of being patient, the subject explains how to get through the calamity that befell him, namely $\mathrm{N}$, for him there is no need to regret his physical condition which can no longer be normal, so the way $\mathrm{N}$ goes through it is by thanking Allah that he is luckier than other people whose disabilities are more severe. from him. RK is almost the same as $\mathrm{N}$, that is, sincerely and resignedly to Allah's provisions, and is grateful.

$\mathrm{K}$, he was able to get through the calamity that befell him, of course thanks to the support from his parents and friends who always encouraged him to be able to live a better life even though he was limited. AN, AN was able to get through the calamity that befell him, namely by praying to Allah. AF, he was able to get through the calamity that befell him of course thanks to the support of his mother, as well as by praying, reciting the Koran and dhikr to Allah SWT. Then PS, for PS he was able to get through everything, namely by continuing to think positively that his life in the future will be better than before.

The calamity that befell the subject and his unfavorable past, subjects $\mathrm{N}, \mathrm{AN}, \mathrm{K}$, $\mathrm{RK}$ and $\mathrm{AF}$ make it a lesson for the future so that life in the future is better than before. with the support of the closest people and awareness arises to be able to change lives for the better and in addition to the subject's stay in the orphanage with the guidance provided by the orphanage so that some research subjects are able to sincerely accept the disability conditions they experience. Meanwhile, the subject of PS uses his past as a reminder and still regrets what happened to him.

Regretting the past that has happened is a phenomenon of hatred against His will. The reality of faith requires that we forget all the disasters that have befallen us and start a new life with hope filled with good deeds and courage. 
In terms of acceptance of the physical disability experienced, subjects N, K, RK and $A F$ who claimed to have been able to accept the disability they experienced, because they believed there was a lesson behind the disability they experienced. Meanwhile, AN admits that sometimes he still feels inferior, especially because of the burn marks on his face. Likewise, PS has not been able to accept the disability he experienced, because his activities are limited and PS still regrets the accident that happened to him. If man is willing to accept the destiny that Allah has determined for him, then the reward is as explained by the Messenger of Allah in his saying, "Indeed, Allah says, "If I put my servant on something he loves, and he is patient, I will replace both of them with Paradise.

Each subject is different in terms of the process of becoming a more patient person. Subjects $\mathrm{N}$ and $\mathrm{AN}$ are now more patient than before because patience is obtained by asking from Allah through prayer and reading the holy Qur'an and also from motivation and advice from the orphanage.

Subject $\mathrm{K}$ is now more patient than before, this is because his life journey from the past until now has been used as a lesson so that $K$ is more grateful and patient, Subject $k$ is more patient than before because his life experience is used as a lesson so that he can let go of what happened to him. PS subjects find it difficult to be patient after being in an orphanage. PS is getting guidance from the orphanage and the motivation from friends at the orphanage is there, even if little by little. And the subject of AF is now more patient than before because a few months before the accident there had been a change in him to learn to be patient and also after being in the AF orphanage he became a more patient person because he received guidance from the orphanage.

According to Said bin Jubair, patience is the servant's awareness of Allah with what has been inflicted on him, and his hope in $\mathrm{Him}$ from the reward for what has been inflicted on him. Sometimes, many people are sad and very sorry for the calamity that befell them, but in the end only patience must be taken(Amen, 2003).

For research subjects, patience is a way to be able to control and control emotions and to be calm in living life. The subject's expression about the importance of patience is in accordance with the results of research conducted by Subandi regarding the concept of patience in psychology which found several categories of patience, one of which is self-control, one of which is to restrain or control emotions.

The theme of the meaning of patience, subjects differ in the meaning of patience. $\mathrm{N}$ interprets patience, which is full of calm thoughts. AN interprets patience as not complaining, not doing bad things and not doing things that are forbidden by Allah. $\mathrm{K}$ interprets patience as being able to endure gracefully over all the trials from Allah while living in this world. RK interprets patience as a way to fight in the way of Allah so that whatever our wishes can be approved and granted by Allah so that it can bring success or happiness in life. PS interprets patience as limiting oneself so as not to be provoked by emotions. And AF means patience, which is to hold back from ridicule, ridicule from people, and always optimistic because behind a disability there will be a good lesson in the future.

The expression of the meaning of patience according to $\mathrm{N}$ and $\mathrm{K}$ is almost the same as what Amr bin Uthman AlMakki explained that patience is steadfastness with Allah and accepting trials calmly and gracefully. (Fad'aq, 2002).

The expression of the meaning of patience according to $\mathrm{AN}$ is almost the same as what Putri and Lukmawati explained (2015) that the meaning of patience is someone who is able to accept a test or trial, which is given by Allah SWT with steadfastness, refrains from anger, refrains from complaining, holds back his tongue from complaining, is able to guard his limbs so that negative things do not happen. .

The expressions of patient meaning Rk and AF are almost the same as those of Subhan El-Hafiz, which states that patience is an active initial response in 
restraining emotions, thoughts, words, and actions that obey the rules for good purposes supported by optimism, never give up, enthusiasm. seek information or knowledge, have the spirit to open alternative solutions, be consistent, and not easily complain (El Hafiz et al., 2013).

The expression of the meaning of patience PS is almost the same as the explanation of Ayif Syafruddin, who explains that patience has three elements, namely, control (soul), verbal control and control of the limbs. A person's patience will be reflected in the extent to which his level and ability to exercise self-control verbally and his limbs(Reza \& Magfiroh, 2016).

Furthermore, the six subjects revealed the factors that influence patience differently, namely like $\mathrm{N}$ which is prayer. AN is good friends and advice from the orphanage and life experience, $\mathrm{K}$ is because of life's journey and support from parents. RK i.e. close to Allah and learn from life experience. and AF is because of worship and always remember the parents.

The subject's expression above is about the factors that make a person more patient, namely closeness to God, namely worship (prayer) and good friends and advice from the orphanage.

Similar to the opinion of Muhammad Ihsan who said that one of the factors that influence patience is by asking Allah for help, as well as friends and a good environment. Meanwhile, PS revealed that he still finds it difficult to be patient because he still regrets his past and is not getting closer to God. Humans may not be able to be patient in facing various tests and trials that Allah has destined to befall them except with Allah's help because humans are weak creatures.

\section{CONCLUSION}

Based on the results of the analysis and discussion in the previous chapter, it can be concluded that patience has an important meaning for people with physical disabilities after an accident. That is the subject $\mathrm{N}$ patient is full of calm mind. The subject of AN patience is not complaining, not doing bad things and not doing things that are forbidden by Allah. The subject of patience is to endure gracefully over all the tests from Allah SWT while living in this world. The subject of RK being patient is the way to fight in the way of Allah so that our wishes are approved and granted so that they can bring success in life. The subject of PS being patient is to limit oneself so as not to be provoked by emotions. And the subject of patient AF is to refrain from ridicule and ridicule from people and always be optimistic about living life because behind the physical defects experienced there will be good lessons in the future.

Apart from the statements above, this study also found factors that could affect the patience of each subject. Subject $N$ and subject $A F$, because they worship Allah (prayer and recite the Koran) and for AF subjects, of course they always remember their parents. The subject of AN, because of good friends and advice from the orphanage. Subject K, because of the journey of life and support from parents. The subject of RK, by getting closer to Allah and learning from life's experiences. While the PS subject admitted that it was difficult to be patient, because of the support from the orphanage, he gradually began to learn to control his emotions.

\section{BIBLIOGRAPHY}

Al Ghazali. (2005). المكتبة الوققية ـاء لوم الدين للكتب المصورةPDF. Dar lbn Hazmi. https://waqfeya.net/book.php?bid=8110

Amin, MR (2003). Spiritual Enlightenment Success Builds a Peaceful and Happy Life. Al-Mawardi Prima.

B Hurlock, E. (2004). Developmental Psychology An Approach Throughout the Life Span, trans. Istiwidayanti and Soedjarwo. Erlangga.

Darmawan, A., \& Lukmawati. (2015). Meaning of patience for therapist (Phenomenological Studies at the Yayasan Bina Autis Mandiri Palembang). Psychic : Journal of Islamic Psychology, 1(1). http://jurnal.radenfatah.ac.id/index.php/p sikis/article/view/556

El Hafiz, S., Rozi, F., Mundzir, I., \& Pratiwi, L. (2013). PSYCHOLOGICAL 
CONSTRUCTION OF PATIENCE. In UHAMKA : Research and Development Institute.

http://lemlit.uhamka.ac.id/berita/articlepenelitian/285-

04042013101044/konstruk-psikologipatian

Fad'aq, AUH (2002). Revealing the Meaning and Wisdom of Patience. PT. Basritama Lantern.

Martono, N. (2016). Social Research Methods: Key Concepts. PT Raja Grafindo Persada.

Miles, MB, Huberman, AM, \& Saldaña, J. (2014). Qualitative data analysis: a methods sourcebook. SAGE Publications, Inc.

Moleong, L. (2013). Qualitative Research Methodology. PT Youth Rosdakarya.

Nuryetty, MT (2012). Profile of people with social welfare problems in Indonesia. Cooperation between the Indonesian Ministry of Social Affairs and the Indonesian Central Statistics Agency. https://catalogue.nla.gov.au/Record/638 1638

Puspasari, D., \& Alfian, IN (2012). The Meaning of Life for Persons with Postnatal Physical Disabilities Due to Accidents. Journal of Clinical Psychology and Mental Health, 1(2). http://journal.unair.ac.id/filerPDF/110810 296_15v.pdf

Putri $\bar{S}$, AA (2015, April 11). Social
Protection, Rights of Persons with Disabilities. Compass. https://national.kompas.com/read/2015/ 04/11/0643015/Perlindungan.Sosial.Hak .Pernyandang.Disabilitas.

Rajab, K. (2011). Psychology of Worship (Prospering the Divine Kingdom in Human Hearts). AMZAH.

Reza, IF, \& Magfiroh. (2016). Psychology of Worship The Role of Religious Rituals in Human Life. Noer Fikri Offset.

Semiun, Y. (2006). Mental Health 1. Canisius.

Shihab, MQ (2018). Tafsir al-Misbah (5th ed.). Heart Lantern.

Sobur, A. (2011). General Psychology. CV. Faithful Library.

Somantri, TS (2006). Extraordinary Child Psychology. Aditama Refika.

Subandi. (2015). Patience: A Psychological Concept. Journal of Psychology, 38(2), 215-227.

https://jurnal.ugm.ac.id/jpsi/article/view/7 654

Sugiyono. (2016). Qualitative Quantitative Research Methods and R\&D. Alphabet.

Ubaedy, A. (2007). The Secret to Success of Believers. Grafindo.

Ubaid, UA (2012). Patience and Gratitude are the Gates of Happiness in this World and the Hereafter. Amzah. 